\title{
Interactions between Two Fungi Strains during Litter Decomposition through a Microcosm Experiment: Different Degradative Enzyme Activities
}

\author{
Yan Chen1, Gaozhong Pu², Bo Lian³, Xiuxia Pei1, Guifang Huang1, Qifeng Wang1, Yanna Lv \\ ${ }^{1}$ School of Pharmacy, Weifang Medical University, Weifang, China \\ ${ }^{2}$ Guangxi Institute of Botany, Guangxi Zhuang Autonomous Region and Chinese Academy of Sciences, Guilin, China \\ ${ }^{3}$ School of Bioscience and Technology, Weifang Medical University, Weifang, China \\ Email: *lynlyna@163.com
}

How to cite this paper: Chen, Y., Pu, G.Z., Lian, B., Pei, X.X., Huang, G.F., Wang, Q.F. and Lv, Y.N. (2018) Interactions between Two Fungi Strains during Litter Decomposition through a Microcosm Experiment: Different Degradative Enzyme Activities. Advances in Enzyme Research, 6, 1-9. https://doi.org/10.4236/aer.2018.61001

Received: February 8, 2018

Accepted: March 23, 2018

Published: March 26, 2018

Copyright $\odot 2018$ by authors and Scientific Research Publishing Inc. This work is licensed under the Creative Commons Attribution International License (CC BY 4.0).

http://creativecommons.org/licenses/by/4.0/

\section{(c) (i) Open Access}

\begin{abstract}
Fungi are the key agents in litter decomposition in forest ecosystems. However, the specific roles of the interactions between different fungal species during litter decomposition process are unclear. To evaluate the interactions, two fungi strains with significantly different morphs were isolated from the soils of Quercus acutissima forest and Pinus massoniana forest, and inoculated in the litter powder of Quercus acutissima leaves and Pinus massoniana needles with grown separately and in coexistence equally through a microcosm experiment. The enzyme activities were determined as a proxy for microbial activities. The results showed that the degradative enzymes involved in litter decomposition showed varying dynamics pattern during the incubation period. The interactions between the two fungi strains are synergism, and benefit to each other according to enzyme activities, suggesting that a fungi strain growth was accelerated by the presence of other fungi strain during litter decomposition process. However, the interactions of the two fungi strains were bilateral antagonism inoculated in the litter powder of Quercus acutissima leaves according to cellobiohydrolase activities. The synergism, despite bilateral antagonism in an exceptional case, may be an important factor controlling the fungal colonization and growth on litter substrate. The results implied that more fungal species may accelerate litter decomposition rates due to their mutual cooperation.
\end{abstract}

\section{Keywords}

Antagonism, Degradative Enzymes, Fungi, Interactions, Litter

Decomposition, Synergism 


\section{Introduction}

The leaf litter aboveground is the main input of nutrients into the forest soil. Therefore, the leaf litter decomposition and its accompanied release of nutrients and formation of soil organic matter are fundamental processes in ecosystem carbon (C) flux, nutrient cycling, and humus formation [1].

It is well known that microorganisms, mainly bacteria and fungi, despite their relatively petty body, are the major primary decomposers involved in litter decomposition and the nutritional basis for the entire soil food web [2]. While, the complete litter decomposition requires the combined actions of a diverse range of microorganisms [3]. Thus, studying the interactions that take place within micro decomposer community can hence be essential for understanding the functioning of forest ecosystems [4], particularly the nutrient cycles. There are some studies to discuss the interactions of bacteria and fungi during litter decomposition process [5] [6] [7] [8]. However, fungi are thought to be more important than bacteria in terms of litter decomposition and play pivotal roles in nutrient cycling [9]. The reason may be due to that fungi can produce a wider range of exoenzymes than bacteria [10] and they are the primary decomposers of recalcitrant compounds, such as lignin which is a major structural component of leaf litter and often limit litter decomposition processes [11]. Therefore, the study of the interactions between different fungal species during litter decomposition process is important to understand their roles in the functioning of forest ecosystems. Regretfully, to our knowledge, only sporadic information exists on the interactions of different fungal species during litter decomposition process [12] [13]. Thus, this study is to assess the interactions of different fungi strains involved in leaf litter decomposition.

It has long been recognized that litter decomposition was driven by exoenzymes [14]. Meanwhile, some studies suggested that exoenzymes are commonly interpreted as indicators of changes in the function of soil micro decomposer communities in response to environmental variation [15] [16]. Thus, the enzyme activities can be used as an indicator of decomposer activities [17] and microbial decomposition [18]. Therefore, the enzyme activities were determined as a proxy for microbial activities to study the interactions between different fungi strains during litter decomposition process in this study.

This study was carried out through microcosm experiment to assess the interactions between two fungi strains with significantly different morphs during decomposition process of the two dominant litters [Quercus acutissima (dominated in broad-leaved forest) leaves and Pinus massoniana (dominated in coniferous forest) needles] in Zijin Mountain, China.

\section{Materials and Method}

\subsection{Site Description}

Five upper-layer $(0-5 \mathrm{~cm})$ soil samples were collected from each of three discrete sites of two main forest types, a broad-leaved forest (dominated by Quer- 
cus acutissima) and a coniferous forest (dominated by Pinus massoniana) in Zijin Mountain $\left(32^{\circ} 5^{\prime} \mathrm{N}, 118^{\circ} 48^{\prime} \mathrm{E}\right)$, Nanjing, China, in September 2015 for fungi isolated. Zijin Mountain has an area of $24 \mathrm{~km}^{2}$, an altitude of $447.1 \mathrm{~m}$, and a subtropical humid climate. The annual mean temperature is $15.4^{\circ} \mathrm{C}$, with a monthly mean temperature reaching a maximum of $28.2^{\circ} \mathrm{C}$ in July and a minimum of $1.9^{\circ} \mathrm{C}$ in January. The rainy season is from June to July, and the average annual precipitation is $1106.5 \mathrm{~mm}$. The litter coverage rate reaches $90 \%$. The soil is classified as slightly acidic Humic Cambisol with a pH of about 5.0 [19]. Considerable amount of nutrients and organic matters are accumulated in the humus layer. The bedrock materials are sandstones and shales. The annual average $\mathrm{pH}$ value of rainfall is approximately 4.98, with an acid rain frequency of approximately $55.8 \%$ [16].

\subsection{Experimental Design}

All the soil samples were then kept in sealed bags and immediately (after $\sim 2 \mathrm{~h}$ ) taken back to the laboratory for further study. Soil samples were passed through a $2-\mathrm{mm}$ sieve to remove foreign matters, such as leaves, plant root, and gravel. All replicated soil samples were then homogenized by thorough mixing and kept in a refrigerator at $4^{\circ} \mathrm{C}$ for in preparation for further processing.

Fungi were isolated from soil samples using dilution plate method with spread plates using Rose Bengal Agar plates $\left(5 \mathrm{~g} \cdot \mathrm{L}^{-1}\right.$ peptone, $18.5 \mathrm{~g} \cdot \mathrm{L}^{-1}$ agar, $10 \mathrm{~g} \cdot \mathrm{L}^{-1}$ glucose, $1 \mathrm{~g} \cdot \mathrm{L}^{-1} \mathrm{KH}_{2} \mathrm{PO}_{4}, 0.5 \mathrm{~g} \cdot \mathrm{L}^{-1} \mathrm{MgSO}_{4}, 0.0133 \mathrm{~g} \cdot \mathrm{L}^{-1}$ Rose Bengal, and $0.1 \mathrm{~g} \cdot \mathrm{L}^{-1}$ chloramphenicol). The plates were incubated at $28^{\circ} \mathrm{C} \pm 2{ }^{\circ} \mathrm{C}$ in darkness for $3-6$ $\mathrm{d}$, and fungal colonies were recognized on the basis of morphological characteristics. About 25 most common fungi strains were isolated. These strains were then incubated in Cellulose Congo-red Medium $\left(20 \mathrm{~g} \cdot \mathrm{L}^{-1} \mathrm{CMC}, 15 \mathrm{~g} \cdot \mathrm{L}^{-1}\right.$ agar, 2 $\mathrm{g} \cdot \mathrm{L}^{-1} \mathrm{KNO}_{3}, 0.5 \mathrm{~g} \cdot \mathrm{L}^{-1} \mathrm{MgSO}_{4}, 1 \mathrm{~g} \cdot \mathrm{L}^{-1} \mathrm{NaCl}, 1 \mathrm{~g} \cdot \mathrm{L}^{-1} \mathrm{Na}_{2} \mathrm{HPO}_{4}, 1 \mathrm{gL} \mathrm{KH}_{2} \mathrm{PO}_{4}$, and $0.2 \mathrm{~g} \cdot \mathrm{L}^{-1}$ Congo-red) for cellulose-degradative fungi strains isolated. In the end, two fungi strains ( $s p$. A and $s p$. B) with significantly different morphs were isolated with the biggest diameters of hydrolytic zone.

Quercus acutissima leaves (BF) and Pinus massoniana needles (CF) were collected from the forest floor of the previously described forest site in the previous section of the paper in September 2014 (initial litter quality is shown in Table 1). All the litter samples were then taken back to the laboratory and oven dried at $70^{\circ} \mathrm{C}$ for $24 \mathrm{~h}$ to achieve constant weight and grind thoroughly. The litter powder of BF and CF were sterilized before fungal incubation, and then selected as $\mathrm{C}$ resource for fungal incubation with $9-\mathrm{mm}$ diameter agar plugs taken from a growing edge of fungal colony, respectively. The two fungi strains were incubated with grown separately and in coexistence equally, respectively. All the cultures were grown in liquid medium $\left(20 \mathrm{~g} \cdot \mathrm{L}^{-1}\right.$ litter powder, $2 \mathrm{~g} \cdot{ }^{\circ} \mathrm{C} \cdot \mathrm{L}^{-1} \mathrm{KNO}_{3}, 0.5$ $\mathrm{g} \cdot{ }^{\circ} \mathrm{C} \cdot \mathrm{L}^{-1} \mathrm{MgSO}_{4}, 1 \mathrm{~g} \cdot{ }^{\circ} \mathrm{C} \cdot \mathrm{L}^{-1} \mathrm{NaCl}, 1 \mathrm{~g} \cdot{ }^{\circ} \mathrm{C} \cdot \mathrm{L}^{-1} \mathrm{Na}_{2} \mathrm{HPO}_{4}$, and $\left.1 \mathrm{~g} \cdot \mathrm{L}^{-1} \mathrm{KH}_{2} \mathrm{PO}_{4}\right)$. All the incubations were performed at $28^{\circ} \mathrm{C} \pm 2{ }^{\circ} \mathrm{C}$ in darkness, in $18 \times 180 \mathrm{~mm}$ test-tube kept on gentle agitation $(120 \mathrm{rpm})$ for 30 days. Three replicates per treatment were systematically harvested from a batch culture after 5, 10, 20, and 30 
Table 1. Initial litter quality of Quercus acutissima leaves and Pinus massoniana needles.

\begin{tabular}{ccc}
\hline Composition & Leaves & Needles \\
\hline Lignin $\left(\mathrm{mg} \cdot \mathrm{g}^{-1}\right)$ & $301.40^{\mathrm{b}}$ & $385.35^{\mathrm{a}}$ \\
Total carbohydrate $\left(\mathrm{mg} \cdot \mathrm{g}^{-1}\right)$ & $485.29^{\mathrm{b}}$ & $526.75^{\mathrm{a}}$ \\
$\mathrm{N}\left(\mathrm{mg} \cdot \mathrm{g}^{-1}\right)$ & $9.25^{\mathrm{a}}$ & $7.99^{\mathrm{b}}$ \\
Lignin: $\mathrm{N}$ & $32.57^{\mathrm{b}}$ & $48.21^{\mathrm{a}}$ \\
C: $\mathrm{N}$ & $52.44^{\mathrm{b}}$ & $65.90^{\mathrm{a}}$ \\
\hline
\end{tabular}

Data with different superscript letters in a row indicate a significant difference $(P<0.05)$.

of incubation for the activities of some degradative exoenzymes determined.

\subsection{Enzyme Activity Determination}

Of all the naturally produced organic matters in litter, cellulose and lignin are the most recalcitrant matters, and are also the most in abundance [10]. Thus, in order to understand the fungal activities during incubation, changes in activities of four exoenzymes involved in the decomposition of cellulose and lignin were determined spectrophotometrically with little modification: cellulase (E.C. 3.2.1.4) [20], cellobiohydrolase (E.C. 3.2.1.91) [20], invertase (E.C. 3.2.1.26) [21], and polyphenol oxidase (E.C. 1.10.3.1) [22]. Activities of the soil enzymes were assayed within $1 \mathrm{~d}$ after sampling.

\subsection{Statistical Analyses}

Data were checked for deviations from normality and homogeneity of variance before analysis. Analysis of variance was applied to assess significant differences between various treatments. Statistically significant differences were set with $P$ values $<0.05$, unless otherwise stated. All analyses were conducted with DPS (version 7.05).

\section{Results}

The activities of the four enzymes involved in litter decomposition showed varying temporal dynamics pattern during the incubation period. Cellulase activities abruptly and significantly increased at first $(5-10 \mathrm{~d}, P<0.05)$ and then slowly decreased later in all treatments (Figure 1(a)). Cellobiohydrolase activities were not significantly changed at first $(5-10 \mathrm{~d}, P>0.05)$, then gradually and significantly decreased in the middle stage $(10-20 \mathrm{~d}, P<0.05)$, and slowly increased in the last stage ( $20-30 \mathrm{~d}$ ) (Figure $1(\mathrm{~b})$ ). Invertase activities sharply decreased at first $(5-10 \mathrm{~d})$ and then maintained steady or continuous decreased latter (Figure 1(c)). Polyphenol oxidase activities increased progressively to the end of the $30 \mathrm{~d}$ incubation in all treatments in most cases, and the activities in the end of incubation were higher $70.69 \%-154.55 \%$ than initial value (Figure 1(d)).

In this study, 1) cellulase activities of the fungi combinations was higher than those of the single-fungi, except inoculated in the litter powder of BF in the 


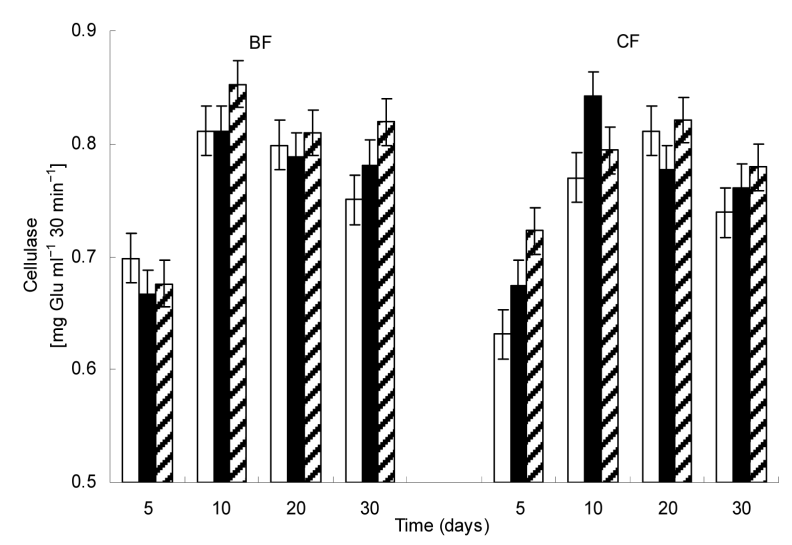

(a)

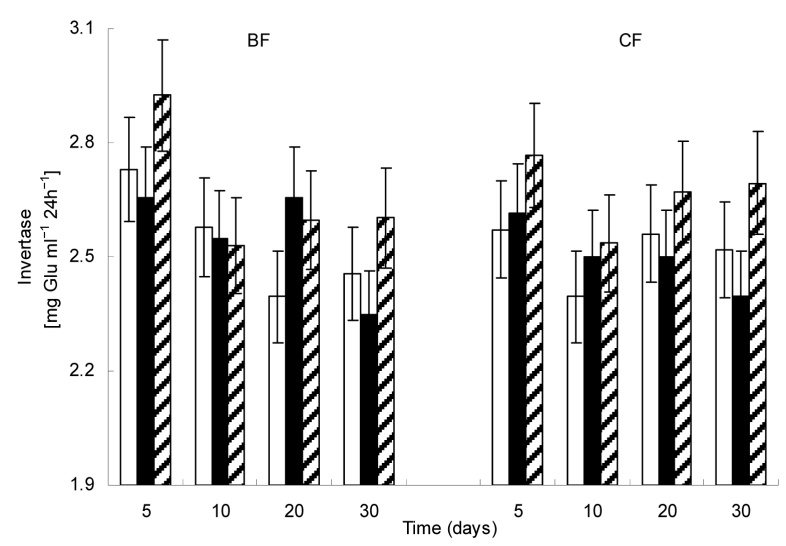

(c)

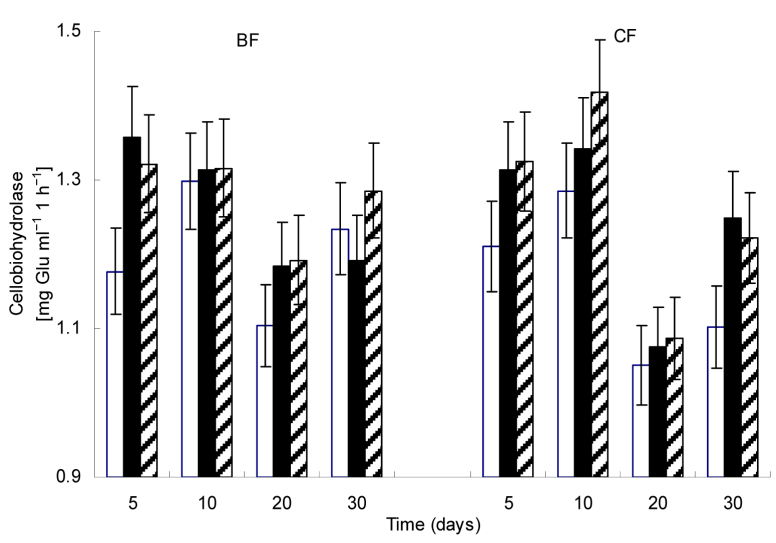

(b)

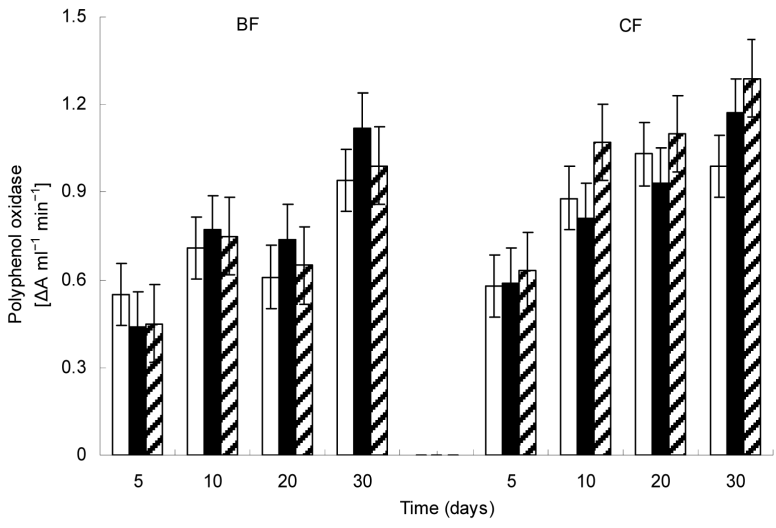

(d)

Figure 1. Changes in enzyme activities during litter decomposition. Legend: (a) cellulase; (b) cellobiohydrolase; (c) invertase; (d) polyphenol oxidase. Symbols: open bar, $s p$. A; filled bar, $s p$. B; lined bar, $s p$. A and $s p$. B. Error bars indicate standard error (SE).

sample of $5 \mathrm{~d}$ and inoculated in the litter powder of CF in the sample of $10 \mathrm{~d}$ (Figure 1(a)), 2) cellobiohydrolase activities of the fungi combinations was higher than those of the single-fungi, except inoculated in the litter powder of $\mathrm{BF}$ in the sample of $5 \mathrm{~d}$ and inoculated in the litter powder of $\mathrm{CF}$ in the sample of 30 $\mathrm{d}$ (Figure 1(b)), 3) invertase activities of the fungi combinations was higher than those of the single-fungi (and there shows a significant difference between the fungi combinations and the single-fungi in the sample of $5 \mathrm{~d}$ and $30 \mathrm{~d}$ in the powder both of the two litters, $P<0.05$ ), except inoculated in the litter powder of BF in the sample of $10 \mathrm{~d}$ and inoculated in the litter powder of CF in the sample of $20 \mathrm{~d}$ (Figure $1(\mathrm{c})$ ), and 4) polyphenol oxidase activities of the fungi combinations was higher than those of the single-fungi inoculated in the litter powder of $\mathrm{CF}$, while there shows opposite result with inoculated in the litter powder of BF (Figure $1(\mathrm{~d})$ ).

To understand the interaction between the two fungi strains, the regression equation of the interactions between the two fungi strains during litter decomposition process were calculated according to enzyme activities (Table 2). The regression equation showed that the interactions between the two fungi strains 
Table 2. Regression analysis of the interactions between the two fungi strains $\left(\mathrm{X}_{\mathrm{A}}, s p . \mathrm{A} ; \mathrm{X}_{\mathrm{B}}, s p . \mathrm{B} ; \mathrm{Y}, s p . \mathrm{A}\right.$ and $\left.s p . \mathrm{B}\right)$ inoculated in the litter powder of Quercus acutissima leaves and Pinus massoniana needles according to enzyme activities.

\begin{tabular}{|c|c|c|c|c|}
\hline \multirow{2}{*}{ Enzyme } & \multicolumn{2}{|l|}{ Leaves } & \multicolumn{2}{|l|}{ Needles } \\
\hline & Regression equation & $\mathrm{R}^{2}$ & Regression equation & $\mathrm{R}^{2}$ \\
\hline Cellulase & $\mathrm{Y}=83.7421-103.6762 \mathrm{X}_{\mathrm{A}}-103.8427 \mathrm{X}_{\mathrm{B}}+128.9102 \mathrm{X}_{\mathrm{A}} \mathrm{X}_{\mathrm{B}}$ & 0.9208 & $\mathrm{Y}=45.8284-59.9538 \mathrm{X}_{\mathrm{A}}-56.1843 \mathrm{X}_{\mathrm{B}}+74.2239 \mathrm{X}_{\mathrm{A}} \mathrm{X}_{\mathrm{B}}$ & 0.5446 \\
\hline Cellobiohydrolase & $\mathrm{Y}=-62.1652+50.5547 \mathrm{X}_{\mathrm{A}}+53.8302 \mathrm{X}_{\mathrm{B}}-43.3070 \mathrm{X}_{\mathrm{A}} \mathrm{X}_{\mathrm{B}}$ & 0.9891 & $\mathrm{Y}=77.1007-62.8307 \mathrm{X}_{\mathrm{A}}-59.8783 \mathrm{X}_{\mathrm{B}}+48.9322 \mathrm{X}_{\mathrm{A}} \mathrm{X}_{\mathrm{B}}$ & 0.8856 \\
\hline Invertase & $\mathrm{Y}=138.2733-50.6023 \mathrm{X}_{\mathrm{A}}-52.2688 \mathrm{X}_{\mathrm{B}}+19.1748 \mathrm{X}_{\mathrm{A}} \mathrm{X}_{\mathrm{B}}$ & $0.7751 \mathrm{Y}$ & $=506.0160-201.9460 \mathrm{X}_{\mathrm{A}}-205.2240 \mathrm{X}_{\mathrm{B}}+81.9988 \mathrm{X}_{\mathrm{A}} \mathrm{X}_{\mathrm{B}}$ & 0.3426 \\
\hline $\begin{array}{l}\text { Polyphenol } \\
\text { oxidase }\end{array}$ & $\mathrm{Y}=6.2803-8.8367 \mathrm{X}_{\mathrm{A}}-8.8869 \mathrm{X}_{\mathrm{B}}+13.0808 \mathrm{X}_{\mathrm{A}} \mathrm{X}_{\mathrm{B}}$ & 0.6965 & $\mathrm{Y}=9.8668-11.0435 \mathrm{X}_{\mathrm{A}}-9.7123 \mathrm{X}_{\mathrm{B}}+11.3387 \mathrm{X}_{\mathrm{A}} \mathrm{X}_{\mathrm{B}}$ & 0.5675 \\
\hline
\end{tabular}

are synergism, and benefit to each other, except the interactions is bilateral antagonism between the two fungi strains inoculated in the litter powder of BF according to cellobiohydrolase activities.

\section{Discussion}

Previous laboratory studies have shown that the interactions between microbial communities can be important for coexistence and community structure [23]. Three cases expected to manifest in the interactions between different fungal species mostly: 1) single-fungi grew better in the absence of one another than when they occurred together. This inferred the bilateral antagonistic relationship between different fungal species. The expression of antagonism may be the competition for substrate and/or space, particularly when the substrate and/or space was limited for fungal metabolism; 2) the interactions are synergism, of benefit to one or both groups from intermediate decomposition products released by the other; and 3) there may be no obvious interactions between different fungal species.

Some studies suggested that the competitive or synergistic interactions between different fungal species may retard or accelerate litter decomposition [13]. For example, the antagonistic interactions among fungi in a diverse community can result in reduced litter decomposition rates [24], and the synergistic interactions among fungal species increased litter decomposition rates significantly [25]. Our results showed that the interactions between the two fungi strains are synergism, and benefit to each other, suggesting that a fungi growth was accelerated by the presence of other fungi in decomposition process. However, the interactions of the two fungi strains were bilateral antagonism in an exceptional case. This suggested that the interactions of the different fungi strains inoculated indifferent resource were varied according to different parameter of fungal growth characteristics, such as the activities of different degradative exoenzymes. It cannot be ignored that the synergistic, despite bilateral antagonism in an exceptional case, may be an important factor controlling the fungal colonization and growth on litter substrate. The mutual cooperation between different fungal species in most cases of the decomposition process may be for the purpose of obtains nutrition, probable utilized intermediate decomposition products re- 
leased by other one. This was corresponding with previous study [25]. The results implicated that more fungal species may accelerate litter decomposition rates duo to their mutual cooperation according to the results of this study. Naeem et al. found a positive correlation between number of microbial species and litter decomposition [26], which Morin attributed to greater numbers of functional groups [27] and Cox et al. attributed to greater numbers of pivotal microbial species [13]. However, Cox et al. suggested that decomposition rates of pine litter inoculated with a single fungal species were higher than when colonized by a diverse community of fungi [13]. Meanwhile, other studies also indicated that litter decomposition by two or three species mixtures of fungi did not exceed that in the best performing monoculture [12]. This suggested that the interactions between different fungal species may vary with different fungal species and/or different substrate. The reason may be that litter decomposition requires the enzyme excretion and activities expression of different fungal species to decompose the structural components of plant litter with different physicochemical properties and recover organic nutrition. Thus, the interactions of enzyme cooperation and population competition create a temporal dynamic that at any particular time is dominated by a relatively small number of populations, whose identity varies with different substance type and habitat [28]. Therefore, the temporal dynamics pattern of litter decomposition was controlled by the fungal activities (or the enzyme excretion and activities expression) and/or the chemical composition of the litter substrate.

Despite an apparent need for cooperation, fungal succession is driven by competition for a dwindling and continually changing substrate [29]. Therefore, we expect that there might be an antagonistic relationship between the two fungal species owing to the competition for substrate and/or space if the incubation period was last for longer time in this study. Meanwhile, there are many microbial species involved in litter decomposition and mineralization [2] and the complete litter decomposition requires their combined actions [3]. Thus, further studies are required to characterize the interactions of greater numbers of different fungal species and/or functional groups to determine their roles in litter decomposition process for longer time.

\section{Acknowledgements}

This work was supported by the National Natural Scientific Foundation of China (31600386, 31660154), the Natural Scientific Foundation of Shandong Province (ZR2015CL014), and Public Teachers' Domestic Visiting Project of Weifang Medical University.

\section{References}

[1] Hoorens, B., Aerts, R. and Stroetenga, M. (2003) Does Initial Litter Chemistry Explain Litter Mixture Effects on Decomposition? Oecologia, 137, 578-586. https://doi.org/10.1007/s00442-003-1365-6

[2] Kuehn, K.A., Gessner, M.O., Wetzel, R.G. and Suberkropp, K. (1999) Decomposi- 
tion and $\mathrm{CO}_{2}$ Evolution from Standing Litter of the Emergent Macrophyte Erianteus giganteus. Microbial Ecology, 38, 50-57. https://doi.org/10.1007/s002489900154

[3] Slater, J.H. and Lovatt, D. (1984) Biodegradation and the Significance of Microbial Communities. In: Gibson, D.T., Eds., Microbial Degradation of Organic Compounds, Marcel Dekker, New York, 439-485.

[4] Treton, C., Chauvet, E. and Charcosset, J.Y. (2004) Competitive Interaction between Two Aquatic Hyphomycete Species and Increase in Leaf Litter Breakdown. FEMS Microbiology Ecology, 48, 439-446. https://doi.org/10.1007/s00248-003-0195-8

[5] Wohl, D.L. and McArthur, J.V. (2001) Aquatic Actinomycete-Fungal Interactions and Their Effects on Organic Matter Decomposition: A Microcosm Study. Microbial Ecology, 42, 446-457. https://doi.org/10.1007/s00248-001-0005-0

[6] Gulis, V. and Suberkropp, K. (2003) Interactions between Stream Fungi and Bacteria Associated with Decomposing Leaf Litter at Different Levels of Nutrient Availability. Aquatic Microbial Ecology, 30, 149-157. https://doi.org/10.3354/ame030149

[7] Romaní, A.M., Fischer, H., Mille-Lindblom, C. and Tranvik, L.J. (2006) Interactions of Bacteria and Fungi on Decomposing Litter: Differential Extracellular Enzyme Activities. Ecology, 87, 2559-2569. https://doi.org/10.1890/0012-9658(2006)87[2559:IOBAFO]2.0.CO;2

[8] Baschien, C., Rode, G., Böckelmann, U., Götz, P. and Szewzyk, U. (2009) Interactions between Hyphosphere-Associated Bacteria and the Fungus Cladosporium herbarum on Aquatic Leaf Litter. Microbial Ecology, 58, 642-650. https://doi.org/10.1007/s00248-009-9528-6

[9] Thormann, M.N. (2006) Diversity and Function of Fungi in Peatlands: A Carbon Cycling Perspective. Canadian Journal of Soil Science, 86, 281-293. https://doi.org/10.4141/S05-082

[10] Kirk, T.K. and Farrell, R.L. (1987) Enzymatic Combustion: The Microbial Degradation of Lignin. Annual Review of Microbiology, 41, 465-505. https://doi.org/10.1146/annurev.mi.41.100187.002341

[11] Osono, T. and Takeda, H. (2005) Decomposition of Lignin, Holocellulose, Polyphenol and Soluble Carbohydrate in Leaf Litter of 14 Tree Species in a Cool Temperate Forest. Ecological Research, 20, 41-49. https://doi.org/10.1007/s11284-004-0002-0

[12] Hedlund, K. and Sjögren, Ö.M. (2000) Tritrophic Interactions in a Soil Community Enhance Decomposition Rates. Oikos, 88, 585-591. https://doi.org/10.1034/j.1600-0706.2000.880315.x

[13] Cox, P., Wilkinson, S.P. and Anderson, J.M. (2001) Effects of Fungal Inocula on the Decomposition of Lignin and Structural Polysaccharides in Pinus sylvestris Litter. Biology and Fertility of Soils, 33, 246-251. https://doi.org/10.1007/s003740000315

[14] Lv, Y.N., Wang, C.Y., Jia, Y.Y., Du, J.J., Ma, X., Wang, W.W., Pu, G.Z. and Tian, X.J. (2013) Responses of Soil Microbial Biomass and Enzymatic Activities to Different Forms of Organic Nitrogen Deposition in the Subtropical Forests in East China. Ecological Research, 28, 447-457. https://doi.org/10.1007/s11284-013-1033-1

[15] Marx, M.C., Wood, M. and Jarvis, S.C. (2001) A Microplate Fluorimetric Assay for the Study of Enzymes Diversity in Soils. Soil Biology \& Biochemistry, 33, 1633-1640. https://doi.org/10.1016/S0038-0717(01)00079-7

[16] Lv, Y.N., Wang, C.Y., Jia, Y.Y., Wang, W.W., Ma, X., Du, J.J., Pu, G.Z. and Tian, X.J. (2014) Effects of Sulfuric, Nitric, and Mixed Acid Rain on Litter Decomposition, Soil Microbial Biomass, and Enzyme Activities in Subtropical Forests of China. 
Applied Soil Ecology, 79, 1-9. https://doi.org/10.1016/j.apsoil.2013.12.002

[17] Laiho, R. (2006) Decomposition in Peatlands: Reconciling Seemingly Contrasting Results on the Impacts of Lowered Water Levels. Soil Biology \& Biochemistry, 38, 2011-2024. https://doi.org/10.1016/j.soilbio.2006.02.017

[18] Moorhead, D.L. and Sinsabaugh, R.L. (2000) Simulated Patterns of Litter Decay Predict Patterns of Extracellular Enzyme Activities. Applied Soil Ecology, 14, 71-79.

[19] FAO-UNESCO (1987) Soils of the World. Elsevier, New York.

[20] Ghose, T.K. (1987) Measurement of Cellulase Activities. Pure and Applied Chemistry, 59, 257-268. https://doi.org/10.1351/pac198759020257

[21] Ohshima, T., Tamura, T. and Sato, M. (2007) Influence of Pulsed Electric Field on Various Enzyme Activities. Journal of Electrostatics, 65, 156-161. https://doi.org/10.1016/j.elstat.2006.07.005

[22] Perucci, P., Casucci, C. and Dumontet, S. (2000) An Improved Method to Evaluate the $o$-Diphenol Oxidase Activity of Soil. Soil Biology \& Biochemistry, 32, 1927-1933. https://doi.org/10.1016/S0038-0717(00)00168-1

[23] Hulot, F.D., Morin, P.J. and Loreau, M. (2001) Interactions between Algae and the Microbial Loop in Experimental Microcosms. Oikos, 95, 231-238. https://doi.org/10.1034/j.1600-0706.2001.950205.x

[24] Boddy, L. (2000) Interspecific Combative Interactions between Wood-Decaying Basidiomycetes. Fems Microbiology Ecology, 31, 185-194. https://doi.org/10.1111/j.1574-6941.2000.tb00683.x

[25] Robinson, C.H., Dighton, J., Frankland, J.C. and Coward, P.A. (1993) Nutrient and Carbon Dioxide Release by Interacting Species of Straw-Decomposing Fungi. Plant and Soil, 151, 139-142. https://doi.org/10.1007/BF00010794

[26] Naeem, S., Hahn, D.R. and Schuurman, G. (2000) Producer Decomposer Co-Dependency Influences Biodiversity Effects. Nature, 403, 762-764. https://doi.org/10.1038/35001568

[27] Morin, P.J. (2000) Biodiversity's Ups and Downs. Nature, 406, 463-464. https://doi.org/10.1038/35020160

[28] Zak, J.C. and Rabatin, S.C. (1997) Organization and Description of Fungal Communities. In: Wicklow, D.T. and Söderström, B., Eds., The Mycota, Vol. 4, Environmental and Microbial Relationships, Springer-Verlag, Berlin, 33-46.

[29] Chet, I., Inbar, J. and Hadar, Y. (1997) Fungal Antagonists and Mycoparasites. In: Wicklow, D.T. and Söderström, B., Eds., The Mycota, Vol. 4, Environmental and Microbial Relationships, Springer-Verlag, Berlin, 165-184. 